\title{
Regulation of endocrine and paracrine sources of Igfs and Gh receptor during compensatory growth in hybrid striped bass (Morone chrysops $\times$ Morone saxatilis)
}

\author{
Matthew E Picha ${ }^{1}$, Marc J Turano ${ }^{\mathbf{1}, 2}$, Christian K Tipsmark ${ }^{\mathbf{1 , 3}}$ and Russell J Borski ${ }^{\mathbf{1}}$ \\ ${ }^{1}$ Department of Zoology and ${ }^{2}$ North Carolina Sea Grant, North Carolina State University, Raleigh, North Carolina 27695-7617, USA \\ ${ }^{3}$ Institute of Biology, University of Southern Denmark, Odense 5230, Denmark \\ (Correspondence should be addressed to R J Borski; Email: russell_borski@ncsu.edu)
}

\begin{abstract}
Compensatory growth (CG) is a period of growth acceleration that exceeds normal rates after animals are alleviated of certain growth-stunting conditions. In hybrid striped bass (HSB, Morone chrysops $\times$ Morone saxatilis), 3 weeks of complete feed restriction results in a catabolic state that, when relieved, renders a subsequent phase of CG. The catabolic state was characterized by depressed levels of hepatic Type I and II GH receptor ( $g h r$, $g h r 2)$ and igf 1 mRNA, along with considerable decreases in plasma Igf1. The state of catabolism also resulted in significant declines in hepatic iff $2 \mathrm{mRNA}$ and in circulating $40 \mathrm{kDa}$ Igfbinding protein (Igfbp). Skeletal muscle expression of $g h r 2$ mRNA was significantly increased. Upon realimentation, specific growth rates (SGRs) were significantly higher than sized-matched controls, indicating a period of CG. Hepatic ghr1,
\end{abstract}

ghr2, igf1 and igf 2 mRNA levels along with plasma Igf1 and $40 \mathrm{kDa}$ Igfbp increased rapidly during realimentation. Plasma Igf1 and total hepatic igf $2 \mathrm{mRNA}$ were significantly correlated to SGR throughout the study. Skeletal muscle igf1 mRNA also increased tenfold during CG. These data suggest that endocrine and paracrine/autocrine components of the GH-Igf axis, namely igf1, igf2, and $g h r 1$ and $g h r 2$, may be involved in CG responses in $\mathrm{HSB}$, with several of the gene expression variables exceeding normal levels during CG. We also demonstrate that normalization of hepatic mRNA as a function of total liver production, rather than as a fraction of total RNA, may be a more biologically appropriate method of quantifying hepatic gene expression when using real-time PCR.

Journal of Endocrinology (2008) 199, 81-94

\section{Introduction}

Growth in teleost fishes involves a complex array of neuroendocrine processes under the direct influence of variables such as temperature, nutrition, and stress. Fish are an excellent model to study the physiological control of variable and often dramatic differences in growth rate since they exhibit indeterminate and relatively plastic rates of growth. Compensatory growth (CG) is a period of growth acceleration that exceeds normal rates after animals are alleviated of certain growth-stunting conditions (Wilson \& Osbourn 1960; see Ali et al. 2003 for review). Experimental regimes that elicit states of CG provide the opportunity to elucidate the underlying mechanisms of stunted (negative), normal, and accelerated (compensatory) growth. While numerous studies in fishes have examined the endocrine growth axis during periods of weight loss, typically induced through feed restriction (see Picha et al. 2008 for review), few have examined the response of the axis during the subsequent period of CG when the stunting condition is removed.

The endocrine control of growth in fishes and other vertebrates is regulated primarily through the growth hormone (Gh)/insulin-like growth factor (Igf) axis (reviewed by Duan 1997, Pérez-Sánchez \& Le Bail 1999, Reinecke 2006). Under anabolic conditions, Gh released from the pituitary acts on its hepatic receptors to stimulate the production and subsequent release of Igf1 into the circulation. Systemic Igf1 can then act on target tissues to promote cell proliferation, differentiation, and ultimately body growth (reviewed by Wood et al. 2005). Accordingly, its levels have been correlated to specific growth rate (SGR) in numerous teleosts (Uchida et al. 2003, Beckman et al. 2004, Picha et al. 2006, 2008, Vera Cruz et al. 2006), and the recent evidence indicates that the presence or absence of a single IGF1 nucleotide polymorphism may determine body size in dogs (Sutter et al. 2007). In addition to hepatic binding, GH may also act directly on target tissues such as skeletal muscle to stimulate the production of IGF1, which in turn can act in a paracrine/autocrine fashion to stimulate tissue growth (Chauvigné et al. 2003). The potential contribution of locally produced Igf1 to anabolism is further underscored by studies in Gh-transgenic tilapia (Oreochromis niloticus), which showed elevated growth and skeletal igf 1 mRNA but reduced plasma Igf1 relative to wild-type controls (Eppler et al. 2007). Unlike postnatal mammals, circulating as well as locally produced Igf2 may also have mitogenic effects in adult fishes (Chen et al. 2000, Peterson et al. 2004, Gabillard et al. 2006, Terova et al. 2007). The anabolic effects of both Igf1 and Igf2 are mediated by Igf-binding 
proteins (Igfbps), four of which have been identified in fishes at the protein level (Igfbp-1, -2, -3, and -5; Shimizu et al. 2003, Kamangar et al. 2006). The putative Igfbp-3 (40-50 kDa), which actually may be an Igfbp-2 paralog (Rodgers et al. 2008), is most commonly associated with anabolic states in fishes and may facilitate Igf actions by increasing Igf half-life in the blood and by mediating their transport from the vascular space to target tissues (reviewed by Kelley et al. 2006). Despite evidence supporting the role of the Gh/Igf axis in regulating growth in ectotherms generally and teleosts specifically, few studies have addressed how most components correspond to variable growth phases, including the accelerated state seen with CG.

The purpose of this experiment was to examine the growth, metabolic, and endocrine characteristics of hybrid striped bass (HSB, Morone chrysops $\times$ Morone saxatilis) during stunted, normal, and accelerated (compensatory) growth. Specifically, we were interested in how Igf1, Igf2, $40 \mathrm{kDa}$ Igfbp, Igf receptor, and Type I Ghr and Type II Ghr might change during catabolism (weight loss) and more particularly during the period of rapid (compensatory) growth that follows the growth-stunting condition.

\section{Materials and Methods}

\section{Animals and experimental design}

Procedures were approved by the North Carolina State University (NCSU; Raleigh, NC, USA) Institutional Animal Care and Use Committee. Freshwater, juvenile (71.4 $\pm 0.8 \mathrm{~g}$; mean \pm s.E.M.) HSB were transported from ponds at the Tidewater Research Station (Plymouth, NC, USA) to indoor tanks at NCSU. One week following transport, fish were evenly distributed to eight 6501 tanks within two identical freshwater recirculating systems (4 tanks/system) equipped with biofiltration and u.v. sterilization. Fish were allowed to acclimate to photoperiod (12-h light:12-h darkness) and water quality parameters (hardness $=170 \mathrm{mg} / \mathrm{l}$; alkalinity $=250 \mathrm{mg} / \mathrm{l}$ ) for 1 month prior to the start of the experiment. All fish were maintained on a daily feeding regimen prior to initiation of the experiment using a commercial pelleted floating feed (Zeigler Bros., Gardners, PA, USA; 40\% protein, 10\% fat). Two tanks from each of the recirculating systems were randomly assigned to control and treatment groups $(N=4$ tanks/group at 50 fish/tank). Control fish were fed twice daily to apparent satiation throughout the 63-day experiment. Treatment fish were fasted for the initial 3 weeks (days 0-21) of the experiment, after which time they were placed on the control, twice daily satiation diet for 6 weeks (days 22-63). Water temperature averaged 24.4 $0 \cdot 04{ }^{\circ} \mathrm{C}$ (mean \pm s.E.M.) throughout the experiment.

\section{Sample procedures}

Body weights ( $\mathrm{g}$ ) and total lengths ( $\mathrm{mm}$ ) were taken from both control and treatment groups at the following points: time 0 , the end of 3 weeks of feed restriction (day 21), and 3 and 6 weeks into refeeding (days 42 and 63). The blood and tissue (liver, muscle) samples were taken from a subsample of fish at these same time points, as well as 8 days into the refeeding period (day 29) to better track the time-course response of variables during CG. Group weights and lengths were taken in fish anesthetized with quinaldine sulfate (B L Mitchell Inc., Leland, MS, USA), while terminal sampling for the blood and tissue collection was conducted on fish anesthetized with buffered tricane methanesulfonate (MS-222; Argent Chemical Laboratories, Redmond, WA, USA). The blood was collected using heparinized $1 \mathrm{cc}$ syringes with 22-gauge needles, dispensed into heparinized $1.5 \mathrm{ml}$ tubes containing aprotinin and kept on ice. Plasma was separated by centrifugation at $4{ }^{\circ} \mathrm{C}$ and stored at $-70{ }^{\circ} \mathrm{C}$ until analyses. The liver and muscle samples were rapidly removed, snap frozen in liquid nitrogen, and then stored at $-70{ }^{\circ} \mathrm{C}$. Fish were deprived of feed $20 \mathrm{~h}$ prior to sampling or group weight and length determinations.

\section{Growth rate and metabolic calculations}

Specific growth rate (SGR) was calculated as $\left(\left(\ln W_{2}-\ln W_{1}\right) /\right.$ $\left.\left(T_{2}-T_{1}\right) \times 100\right)$, where $W_{2}$ is the weight at the end of the growth interval and $W_{1}$ is the weight at the beginning of the growth interval, while $T_{2}-T_{1}$ represents the duration (days) of the growing interval. SGRs were calculated for control and treatment fish during the following time intervals: days 0-21, 22-42, 43-63. Hepatosomatic index (HSI) was calculated as $(($ liver wt/body wt $) \times 100)$ and feed conversion ratio $($ FCR $)$ as (feed consumed/weight gain). Percent body weight consumed per day $(\% \mathrm{BW} / \mathrm{d})$ at specific intervals throughout the experiment was calculated as ((total feed consumption per time interval)/(total fish weight estimated at midpoint of the interval $) \times 100)$.

\section{Gene cloning}

Striped bass ( $M$. saxatilis) igf2 (180 bp), Type I Ghr (ghr1; $476 \mathrm{bp}$ ), and Type II Ghr ( $g h r 2 ; 670 \mathrm{bp}$ ) genes were partially cloned in order to design effective primers and probes for measures of mRNA by quantitative real-time PCR (qRTPCR). Total RNA was extracted from striped bass liver samples using TRI Reagant isolation solution (Molecular Research Center; Cincinnati, OH, USA), DNase treated (Ambion; Austin. TX, USA), and then quantified via Nanodrop spectrophotometry (NanoDrop Technologies; Wilmington, DE, USA). One microgram of total RNA was reverse transcribed using oligo $\mathrm{d}(\mathrm{t})$ primers and then $10 \%$ of the $\mathrm{RT}$ reaction used for PCR (Qiagen). Degenerate igf2 primers (Forward: $5^{\prime}$-TGTGGRGGAGARCTGGTGGA-3'; Reverse: 5'-ACTTGGCRGGTTTGGCACAG-3') were designed within the B and A/D domains of the igf 2 gene using known Cottus scorpius (GenBank Accession Number Y16643), Oncorhynchus mykiss (M95184), Paralichthys olivaceus (AF091454), and Oreochromis mossambicus (Y18691) igf2 sequences. Degenerate ghr1 primers (Forward: 5'-TCCTGCACCYAAAATYAAAGG-3'; Reverse: 5'-CTGGGSCCCYCCAGTTTGG-3') were designed within the 
Box 1 region and downstream of the Box 2 region of the cytoplasmic domain using ghr 1 sequences from Scophthalmus maximus (GenBank Accession Number AF352396), Acanthopagrus schlegelii (AF502071), Sparus aurata (AF438176), O. mossambicus (AB115179), and Dicentrarchus labrax (AF438177). Degenerate $\mathrm{ghr} 2$ primers (Forward: 5'-CCTGGGTGGARTTCATCGA-3'; Reverse: 5'-CACCYTCKACCACRGTGTAGACA- ${ }^{\prime}$ ) were designed within and downstream of the Box 2 region of the cytoplasmic domain using $g h r 2$ sequences from A. schlegelii (AY662334), S. aurata (AY573601), O. niloticus (AY973233), and D. labrax (AY642116). PCR cycling conditions were as follows for both genes: 1 cycle at $95^{\circ} \mathrm{C}$ for $15 \mathrm{~min} ; 30$ cycles at $94^{\circ} \mathrm{C}$ for $30 \mathrm{~s}, 50-65^{\circ} \mathrm{C}$ for $30 \mathrm{~s}$, and $72{ }^{\circ} \mathrm{C}$ for $1 \mathrm{~min}$; and $1 \mathrm{cycle}$ at $72^{\circ} \mathrm{C}$ for $10 \mathrm{~min}$. PCR products were ligated into pCR 2.1 vectors and transformed using INV $\alpha \mathrm{F}^{\prime}$ chemically competent Escherichia coli cells (Invitrogen). Plasmids were sequenced at the University of Chicago DNA sequencing facility and verified by BLAST search (NCBI: Bethesda, MD, USA).

\section{$R N A$ isolation for quantitative real-time PCR}

Total RNA was extracted from liver samples using TRI Reagant isolation solution with sequential high salt (Molecular Research Center) and $\mathrm{LiCl}$ precipitation steps intended to remove glycogen contamination (Barlow et al. 1963). The mean 260:230 nm ratio for these RNA samples ranged from 1.35 to $2 \cdot 28$ as determined by Nanodrop spectrophotometry. This wide range and low values in 260:230 ratios suggested residual polysaccharide contamination (Nanodrop Technical Support Bulletin T009), which can artificially alter RNA quantification since glycogen can absorb at $260 \mathrm{~nm}$ (unpublished data). Therefore, samples were further purified with Plant RNA Isolation Aid (Ambion) to completely remove glycogen. Specifically, Plant RNA Isolation Aid was added to RNA samples dissolved in water at a 1:1 $\mathrm{v} / \mathrm{v}$, incubated at room temperature for $10 \mathrm{~min}$, and then spun at $15000 \mathrm{~g}$ for $15 \mathrm{~min}$. The RNA-containing supernatant was removed from the glycogen pellet and then reprecipitated with $\mathrm{LiCl}(2 \cdot 5 \mathrm{M})$. Subsequently, all samples had 260:230 values of $2 \cdot 0-2 \cdot 2$, indicating that they were essentially glycogen free. This, combined with the sample 260:280 ratios of $1 \cdot 9-2 \cdot 0$, indicates high purity of nucleic acids and minimal contamination by proteins and polysaccharides. Muscle samples were extracted using the standard Tri Reagant RNA isolation protocol (Molecular Research Center).

\section{Quantitative real-time PCR}

Quantitative real-time PCR (qRTPCR) primers and Taq Man probes for HSB (Order Perciformes) were designed for igf1, igf2, igfr, and $g h r 1$ and $g h r 2$ in regions with low identity to related genes (Table 1). The igf1 primers and probe showed no cross-reactivity when run with igf 2 cDNA template. Likewise, no cross-reactivity was observed using igf 2 primers and probe with igf1 cDNA template. HSB igfr primers and probe

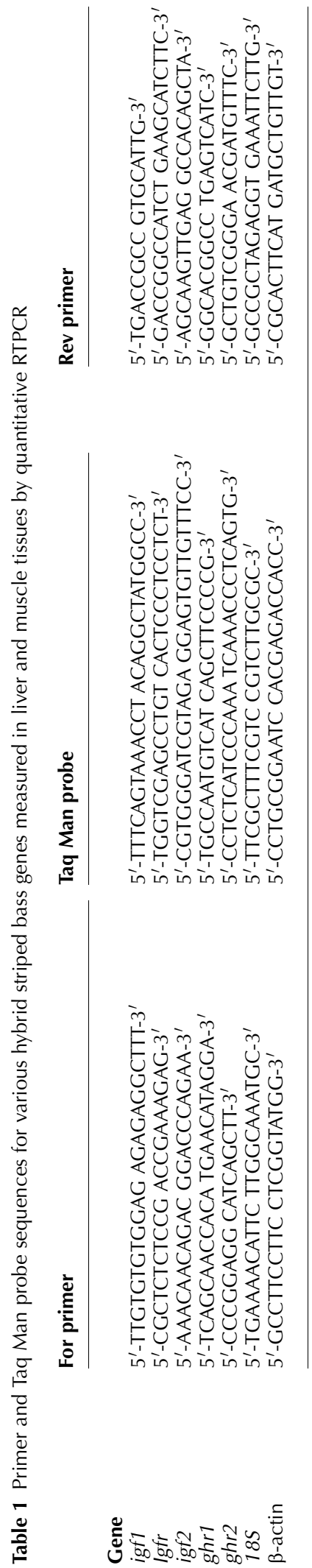

Journal of Endocrinology (2008) 199, 81-94 
were designed within the tyrosine kinase domain (AF402674) that exhibits only $63 \%$ nucleic acid sequence similarity to insulin receptor of another perciform, the tilapia ( $O$. mossambicus, AF493794). No cross-reactivity was observed using $g h r 1$ primers and probe with $g h r 2$ cDNA template or when using ghr2 primers and probe with ghr1 cDNA template.

Following total RNA extraction, muscle and liver RNA from experimental samples were double DNase treated, diluted to the same concentration, and then subjected to reverse transcription (RT) using random hexamer primers (Applied Biosystems; Foster City, CA, USA). Enzymatic reactions for all samples for each tissue type were performed at the same time with identical reagents, as to reduce the variability of DNase and RT efficiency between the samples. Housekeeping genes were also run for all tissue samples to further account for these same variables. cDNAs of 10 (liver) or $100 \mathrm{ng}$ (muscle) from the RT reaction were then loaded with $900 \mathrm{nM}$ primers and $250 \mathrm{nM}$ probes into $20 \mu \mathrm{l}$ qRTPCR volumes containing Brilliant QPCR master mix ( $1 \times$; Stratagene; La Jolla, CA, USA). Quantitative RTPCR assays for each gene were run on an ABI 7900 Thermal Cycler (Applied Biosystems) under the following conditions: 1 cycle at $50{ }^{\circ} \mathrm{C}$ for $2 \mathrm{~min}, 1$ cycle at $95^{\circ} \mathrm{C}$ for $10 \mathrm{~min}$, and then 40 cycles of $95^{\circ} \mathrm{C}$ for $15 \mathrm{~s}$ and $60^{\circ} \mathrm{C}$ for $1 \mathrm{~min}$. No amplification (DNase-treated RNA instead of cDNA) as well as no template (no cDNA) controls were run in parallel with experimental samples to confirm the absence of genomic DNA and qRTPCR reagent contamination respectively. The absolute quantity of specific muscle mRNAs was calculated using cDNA copy number standard curves $\left(10^{0}\right.$ to $10^{-9}$ copy number) generated through gene-specific PCR amplification and isolation according to previously established procedures (Bustin 2000, Picha et al. 2006). Copy number data for all experimental muscle samples were then normalized to total RNA loaded into each qRTPCR assay, and are therefore expressed as copy number per ng RNA. Our initial studies found that changes in skeletal muscle mRNA are similar whether normalized to total RNA or the $\beta$-actin housekeeping gene.

Liver igf1, igf2, ghr1, and $g h r 2$ mRNA data were initially expressed as copy number as a fraction of total RNA (copy number per ng RNA) as described above (Fig. 3A, Table 3). We found here and previously that hepatic mRNA data were similar whether expressed as copy number per ng total RNA or when normalized to the housekeeping gene $18 S$ (Picha et al. 2006), indicating that the processing of tissue samples into cDNA did not result in significant errors in RNA quantification or variability in RT efficiency. Our studies found that $\beta$-actin was regulated in the liver by nutritional state. Hepatic gene expression data were also expressed as total copy number for the entire liver relative to body weight ((ng total liver RNA X copy number of gene per ng RNA)/ (g body weight); Figs 3 and 4). We argue that this latter method is more physiologically relevant for quantifying liver gene expression levels when hepatosomatic indices and total liver RNA content fluctuates dramatically due to nutritional state.

\section{$R I A$}

Circulating levels of total Igf1 were measured from acid/ethanol extracted plasma by RIA using recombinant barramundi Igf1 as tracer and standard, rabbit anti-barramundi Igf1 primary antibody (Novozymes GroPep; Adelaide, Australia) and goat anti-rabbit secondary antibody (Sigma) according to previously described methods (Shimizu et al. 2000, Picha et al. 2006). Barramundi Igf1 was iodinated using the chloramine-T method and purified by column chromatography. Tracer $\left({ }^{125}\right.$ I-barramundi Igf1) was diluted to 20000 c.p.m. for each assay tube. Our previous validation shows that serially diluted HSB plasma produces a displacement curve that parallels that of the barramundi standard (Picha et al. 2006). All samples were run in triplicate.

\section{Western ligand blot}

HSB $40 \mathrm{kDa}$ Igfbp was measured in plasma by western blot according to previously published procedures used for striped bass (Siharath et al. 1995a,b). HSB plasma samples $(4 \mu \mathrm{l})$ along with rat serum (positive control) were run on discontinuous $4 \%$ stacking, $12 \%$ separating SDS-PAGE gels under non-reducing conditions. Following electrophoresis, proteins were electrotransferred overnight onto nitrocellulose membranes, stained with Coomassie blue, and then blocked with TBS + 1\% BSA for $4 \mathrm{~h}$. Hybridization took place overnight at room temperature using ${ }^{125}$ I-barramundi Igf1 at 200000 c.p.m./ml incubating buffer. Membranes were exposed to film in cassettes using intensifying screens at $-70^{\circ} \mathrm{C}$. All data were analyzed using Image Quant 5.2 software (GE Healthcare, Piscataway, NJ, USA) and are expressed as arbitrary density units.

\section{Statistical analyses}

Body weight was analyzed by Repeated Measures ANOVA followed by Fisher's least significant difference (LSD) test for predetermined comparisons (Steele \& Torrie 1980). Correlations were analyzed by regression analysis. All other data were analyzed with a two-way ANOVA (treatment $X$ time) followed by Fisher's LSD test. Statistical analyses were performed with Statistica 7.0 software (Stat Soft, Tulsa, OK, USA). The Nvalue for all growth (weight, SGR) and feed (\% BW/d, FCR) data was represented by mean values of tanks, while individual fish served as the $N$ value for all endocrine parameters. Statistical significance was set at a level of $P \leq 0 \cdot 05$. All data are presented as mean \pm S.E.M.

\section{Results}

\section{Effects of cyclic feeding on growth and metabolic indices}

Three weeks of complete feed restriction (days 0-21) in treatment fish resulted in a $7.7 \%$ decrease in body weight (Fig. 1A), indicated by a negative SGR $(-0 \cdot 38 \pm 0 \cdot 05$; Fig. 1B). 

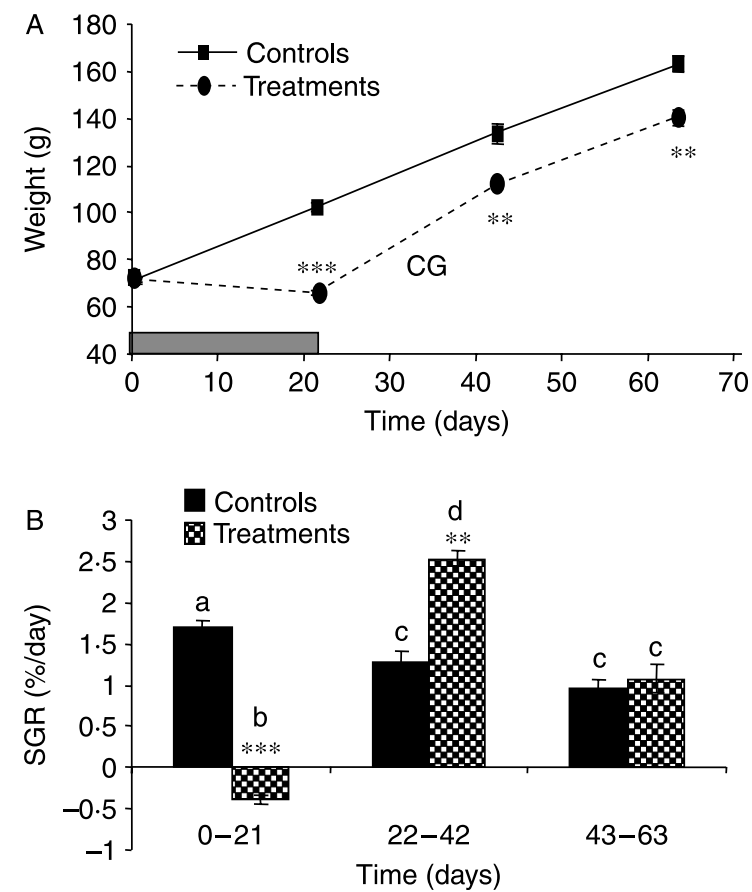

Figure 1 (A) Mean body weight (g) and (B) specific growth rates (SGR; \%/day) of control HSB fed to satiation twice daily and treatment fish subjected to 3 weeks feed restriction (grey bar) followed by 6 weeks of refeeding. CG indicates a period of compensatory growth for treatment fish as defined by elevated SGRs relative to similar-sized controls (time 0 controls $=71 \cdot 4 \pm 1 \cdot 3 \mathrm{~g}$; day 21 treatments $=65 \cdot 8 \pm 0 \cdot 7 \mathrm{~g}$ ). Asterisks represent significant differences between groups at each time point $(* * P<0 \cdot 01$; $* * * P<0 \cdot 001 ; N=$ average values of individual tanks with 4 replicate tanks/group and 30-50 fish/tank). Letters represent significant differences within and between groups across time $(P<0 \cdot 05)$

During the subsequent 3 weeks of refeeding (days 22-42), however, SGRs for treatment fish were significantly higher $(P<0 \cdot 05)$ than those for controls at all growth intervals throughout the experiment (Fig. 1B). Since growth rates are dependent on size and show an allometric relationship with body mass, it is also important to compare growth of similar sized fish. We found that elevations in SGR in treatment fish during the realimentation period was still higher compared with control fish of a similar initial size (Time 0 controls $=71 \cdot 4 \pm 1.3 \mathrm{~g}$; day 21 treatments $=65.8 \pm 0.7 \mathrm{~g})$. The elevated SGR that characterizes CG subsequently declined back to basal levels during weeks 4-6 of realimentation (days 43-63), where there was no significant difference in SGR in treatment fish relative to size-matched controls (control SGR days $22-42=1 \cdot 3 \pm 0 \cdot 1 \%$ / day; treatment SGR days $43-63=1 \cdot 1 \pm 0 \cdot 2 \%$ /day; Fig. 1 ).

In conjunction with the weight loss experienced during feed restriction (days 0-21), HSI values for treatment fish dropped $3 \cdot 5$-fold $(3 \cdot 85 \pm 0 \cdot 11$ to $1 \cdot 11 \pm 0 \cdot 11 ; P<0 \cdot 001)$ and were significantly lower than controls (Fig. 2; $P<0 \cdot 001$ ). Eight days into realimentation and the initial CG response (day 29), treatment HSI values increased by $168 \%$, and

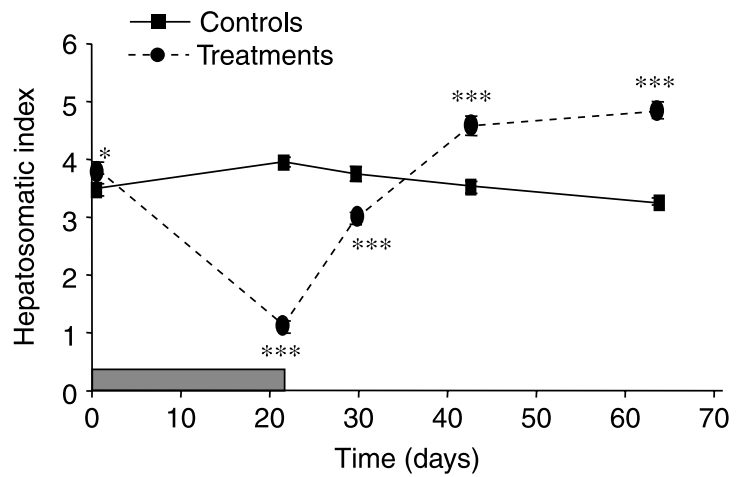

Figure 2 Hepatosomatic index of control HSB fed to satiation twice daily and treatment fish subjected to 3 weeks feed restriction (grey bar) followed by 6 weeks of refeeding twice daily to satiation.

Asterisks represent significant differences between groups at each time point $\left({ }^{*} P<0 \cdot 05 ;{ }^{* *} P<0 \cdot 01 ;{ }^{* *} P<0 \cdot 001 ; N=16\right.$ fish/group).

reached higher levels than controls by 3 weeks (day 42: controls $=3 \cdot 53 \pm 0 \cdot 09$; treatments $=4 \cdot 60 \pm 0 \cdot 16 ; P<0 \cdot 001$ ). This overcompensation persisted through the end of the experiment (day 63: controls $=3 \cdot 27 \pm 0 \cdot 07$; treatments $=$ $4 \cdot 85 \pm 0 \cdot 14 ; P<0 \cdot 001)$.

\section{Feed consumption and feed conversion}

Control fish, which were fed twice daily to apparent satiation, had a gradual yet significant increase in FCR throughout the experiment (Table $2 ; P<0 \cdot 01$ ), coupled with a gradual and significant decrease in feed consumption $(\% \mathrm{BW} / \mathrm{d}$; Table 2; $P<0 \cdot 001)$. While no data was available for either of these parameters during feed restriction for treatment HSB, the subsequent CG response (days 22-42) was marked by both hyperphagia $(2 \cdot 46 \pm 0.05 \% \mathrm{BW} / \mathrm{d}$ for treatments, $1.48 \pm$ $0.05 \% \mathrm{BW} / \mathrm{d}$ for controls; $P<0.01$ ) and improved feed conversion $(0.87 \pm 0.03$ for treatments, $1 \cdot 14 \pm 0 \cdot 07$ for controls; $P<0.01$; Table 2). Both feed consumption and FCRs returned to control values 4-6 weeks into the refeeding period in treatment fish, coinciding with the decline in CG response. Overall, FCR (days 0-63) for treatment fish was statistically similar to that of controls. A highly significant and positive correlation was obtained between feed consumption $(\% \mathrm{BW} / \mathrm{d})$ and HSI values $\left(R^{2}=0 \cdot 64 ; P<0 \cdot 001\right)$, suggesting that HSI may be used as a biomarker for varying degrees of feeding intensity, including periods of feed deprivation.

\section{Gene cloning}

Sequencing results indicated that the striped bass (M. saxatilis) amplicon generated with degenerate igf2 primers (EU419619) shared $98 \%$ nucleotide identity with the closely related European sea bass (D. labrax) igf2 (Terova et al. 2007), confirming we cloned a partial sequence of igf 2 in striped bass. The striped bass amplicon generated with degenerate $g h r 1$ primers (EU419618) shared 84 and 94\% nucleotide identity with gilthead sea bream (S. aurata; Saera-Vila et al. 2005, Jiao 
Table 2 Feed conversion ratios and feed consumption of control fish fed to satiation twice daily and treatment fish subjected to 3 weeks feed restriction (days 0-21) followed by 6 weeks of refeeding twice daily to satiation (days 22-42,43-63). No data was available for treatments during days $0-21$ because fish were not fed during this time. Treatment HSB had improved feed conversion and increased feed consumption during the CG response (days 22-42).

Feed conversion ratio

\section{Feed consumption}

\begin{tabular}{|c|c|c|c|c|}
\hline & & & & \\
\hline & Control & Treatment & Control & Treatment \\
\hline Days & & & & \\
\hline $0-21$ & $0.97 \pm 0.01$ & $\mathrm{~N} / \mathrm{A}$ & $1 \cdot 56 \pm 0 \cdot 07$ & $\mathrm{~N} / \mathrm{A}$ \\
\hline $22-42$ & $1 \cdot 14 \pm 0 \cdot 07$ & $0 \cdot 87 \pm 0.03^{*}$ & $1 \cdot 48 \pm 0 \cdot 05$ & $2 \cdot 46 \pm 0 \cdot 05^{*}$ \\
\hline $43-63$ & $1 \cdot 20 \pm 0 \cdot 07$ & $1 \cdot 23 \pm 0 \cdot 08$ & $1 \cdot 11 \pm 0.06$ & $1 \cdot 25 \pm 0 \cdot 12$ \\
\hline
\end{tabular}

${ }^{*} P<0 \cdot 01$ represents significant differences from controls at the same time point. $N=4$ tanks/group with 30-50 fish/group.

et al. 2006) and European sea bass ghr1 sequences respectively, and only $54 \%$ identity with the striped bass ghr 2 sequence (EU595732). Based on these identities with closely related species, we consider the striped bass amplicon a partial clone of the putative Type I Ghr and hence refer to it here as Ghr1. The striped bass amplicon generated with degenerate $g h r 2$ primers (EU595732) shared 83 and 96\% nucleotide identity with gilthead sea bream (S. aurata; Saera-Vila et al. 2005, Jiao et al. 2006) and European sea bass ghr 2 sequences respectively. Based on these identities with closely related species, we consider the striped bass amplicon a partial clone of the putative Type II Ghr and hence refer to it here as Ghr2.

It should be noted that it is not certain whether the Ghr1 in non-salmonid fishes is a true Ghr (Jiao et al. 2006, Li et al. 2007) or instead the somatolactin receptor (SLR; Fukada et al. 2005, Fukamachi et al. 2005, Pierce et al. 2007). Recent phylogentic and evolutionary analysis suggests that the SLR may in fact be a duplicated Ghr that occurred during the fish-specific genome duplication (Fukamachi \& Meyer 2007). The striped bass $g h r 1$ amplicon showed 70 and $72 \%$ nucleotide identity with medaka (Oryzias latipes; DQ002886; Fukamachi et al. 2005), and masu salmon (Oncorhynchus masou; AB121047; Fukada et al. 2005) slr respectively, while our striped bass $g h r 2$ amplicon only showed 50 and $53 \%$ nucleotide identity to these same $s l r$ sequences.

\section{Hepatic gene expression}

When hepatic igf1 qRTPCR data were normalized to copy number/ng total RNA (Fig. 3A), 3 weeks of feed restriction in treatment fish (days 0-21) resulted in a $27 \%$ increase in igf 1 copy number $(P<0 \cdot 05)$, followed by a subsequent decline 8 days into realimentation and the CG response (day 29; $P<0 \cdot 001$ ). These same trends were observed when data were normalized to the housekeeping gene $18 \mathrm{~S}$. While data normalized in either of these ways represent the most common methods for expressing hepatic mRNA levels and are an accurate reflection of gene expression trends relative to a fraction of total liver RNA, they do not take into account the total amount of mRNA produced by the liver and presumably the protein released into the circulation. Indeed, during nutritional manipulations, the liver shows dramatic fluctuations in size relative to body weight, as indicated by HSI values in this study (see Fig. 2). Similarly, total hepatic RNA content also fluctuates with HSI $\left(R^{2}=0 \cdot 41\right.$; $P<0 \cdot 001$ ), whereby feed-deprived fish having lower HSI values have the least amount of total liver RNA, and vice versa for fish in an anabolic state. Therefore, in order to determine the actual amount of a specific mRNA and potentially the protein produced in response to nutritional status, we accounted for gene expression output for the entire liver. For this reason, we expressed the results for igf1 and all other hepatic mRNAs as total liver mRNA as a function of body weight (total liver copy number/BW).

When hepatic igf1 gene expression was expressed as total amount of hepatic mRNA as a function of body weight (total liver igf1 copy number/body weight), control fish experienced no significant variations throughout the experiment (Fig. 3B). This pattern of gene expression in control fish is virtually identical to that seen when hepatic gene expression is normalized as a fraction of total RNA (Fig. 3A). This would be expected in livers where little change occurs in HSI. Following feed restriction, treatment HSB experienced a 3.5fold decline in total hepatic igf 1 mRNA levels $(P<0 \cdot 001$; Fig. 3B) that were $64 \%$ lower than control fish at day 21 $(P<0 \cdot 01)$. Upon refeeding, levels rose 8 days into the $\mathrm{CG}$ response, the shortest time point measured (day 29; $P<0 \cdot 05$ ). By 3 weeks of realimentation, a $530 \%$ increase in total igf1 mRNA was observed that exceeded control values (day 42; $P<0 \cdot 001)$. This dramatic rise and overcompensation in total hepatic igf1 mRNA that coincides with the duration of the CG response was subsequently restored to control levels by the end of the experiment.

With regard to igf2 gene expression, no significant changes in total hepatic mRNA levels were observed for control fish during the initial 3 weeks. After this point levels slowly declined and plateaued by the end of the experiment (Fig. 4A), possibly representing an allometric pattern of gene expression associated with increased body size in naturally growing individuals. Treatment HSB, on the other hand, experienced an over sixfold decline in total liver igf 2 mRNA following 3 weeks of complete feed restriction $(P<0 \cdot 001)$. Despite this precipitous decline, levels rose by $377 \%(P<0 \cdot 001)$ and had completely caught up to controls 8 days into refeeding and the CG response. After this initial increase, values continued to rise for the remainder of the CG 

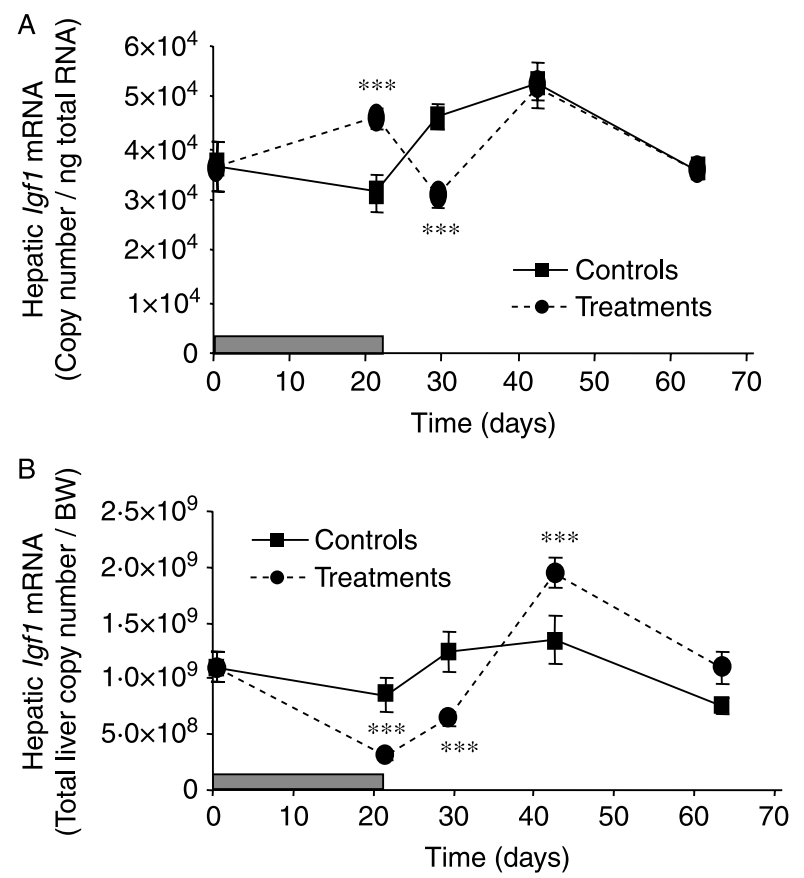

Figure 3 Hepatic mRNA levels of igf1 in control HSB fed to satiation twice daily and treatment fish subjected to 3 weeks feed restriction (grey bar) followed by 6 weeks of refeeding twice daily to satiation. Hepatic mRNA levels were expressed as (A) igf1 copy number/ng total RNA and (B) total hepatic igf1 copy number/body weight. Asterisks represent significant differences between groups at each time point $(* * * P<0 \cdot 001 ; N=6-8$ fish/group).

response (day 42), exceeding that of control fish by $2 \cdot 7$-fold $(P<0 \cdot 001$; Fig. 4A). However, this elevation at day 42 relative to controls may be somewhat diminished when considering mRNA levels as an allometric function of body weight. Similar to trends for hepatic igf1 gene expression, igf 2 mRNA declined back to control levels over the final 3 weeks of realimentation (days 43-63), the period over which CG was not observed. Altogether, a significant correlation was achieved between total liver igf $2 \mathrm{mRNA}$ and SGR $\left(R^{2}=0 \cdot 43 ; P<0 \cdot 001\right.$; Table 4$)$.

Alterations in $g h r 1$ and $g h r 2$ mRNA were similar to that observed for igf 2 mRNA. For ghr1, no significant changes were observed in controls during the first 29 days of the experiment, after which time they underwent a slight decrease and then remained level for the remainder of the trial (Fig. 4B). Treatment fish experienced a fivefold decline in total hepatic ghr $1 \mathrm{mRNA}$ levels during 3 weeks of feed deprivation $(P<0 \cdot 001)$, followed by a rapid, $3 \cdot 2$-fold increase upon 8 days of refeeding $(P<0 \cdot 001)$. By 3 weeks of realimentation, ghr1 levels surpassed that of control fish $(P<0.05)$ and reached similar levels by the end of the experiment. Strong correlations were achieved between total hepatic ghr1 mRNA and both total liver igf1 and igf $2\left(R^{2}=\right.$ 0.41 and 0.67 , respectively; $P<0 \cdot 001$; Table 4). Control levels of total hepatic ghr 2 mRNA did not change throughout
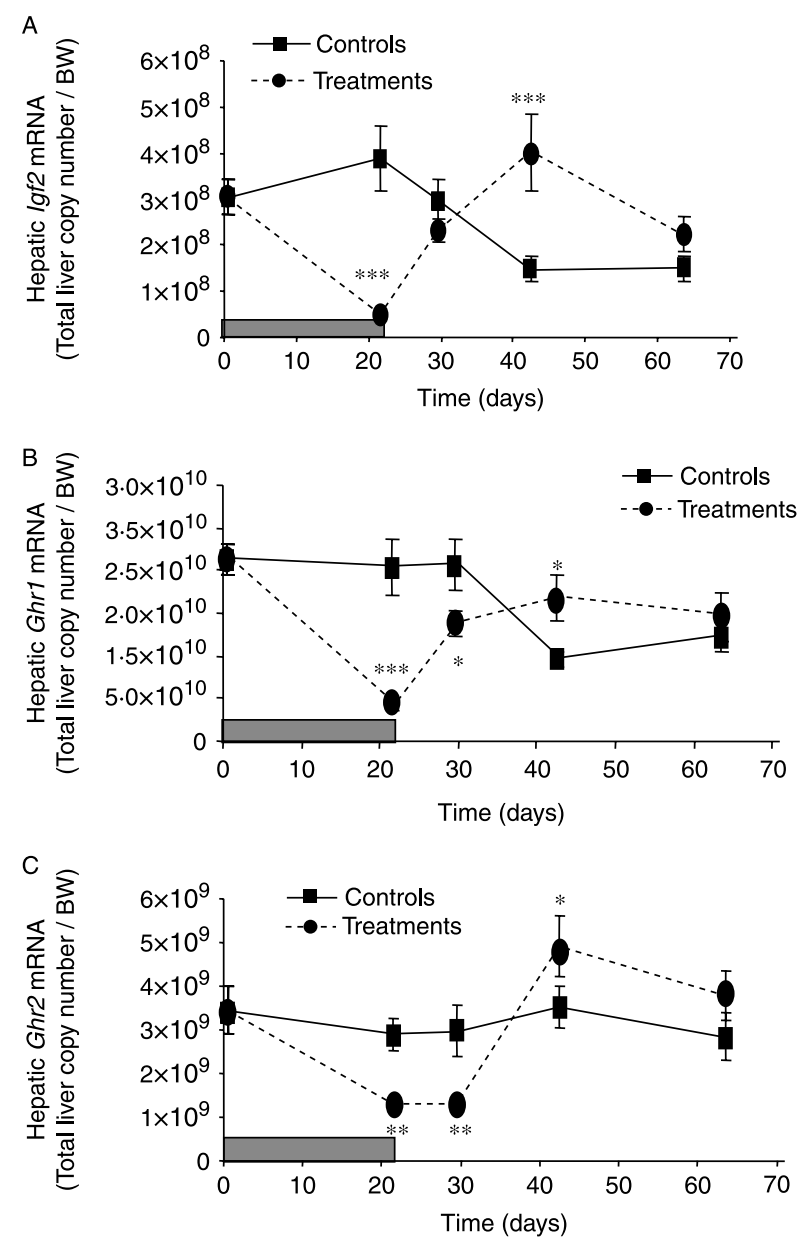

Figure 4 Total hepatic mRNA levels for (A) igf2, (B) the Type I Ghr (ghr1), and (C) Type II Ghr (ghr2) in control HSB fed to satiation twice daily and in treatment fish subjected to 3 weeks feed restriction (grey bar) followed by 6 weeks of refeeding twice daily to satiation. Asterisks represent significant differences between groups at each time point $\left({ }^{*} P<0 \cdot 05 ;{ }^{* *} P<0 \cdot 01 ;{ }^{* *} P<0 \cdot 001 ; N=6-8\right.$ fish/group).

the experiment (Fig. 4C). By contrast, treatment fish experienced a $63 \%$ decline following starvation $(P<0 \cdot 001)$. Expression levels did not change 8 days into refeed (day 29) and the CG response; however, values increased by over $275 \%$ $(P<0 \cdot 001)$ to levels above controls after 3 weeks of realimentation (day $42 ; P<0 \cdot 05$ ). No significant differences were observed between groups by day 63 . Strong correlations were achieved between total hepatic ghr2 mRNA and both total liver igf1 and igf $2\left(R^{2}=0.68\right.$ and $0 \cdot 31$ respectively; $P<0 \cdot 001$; Table 4).

Data for hepatic igf2, ghr1, and $g h r 2 \mathrm{mRNA}$ expressed as copy number/ng total RNA are also provided for normalization comparison purposes (Table 3). However, we do not discuss these data in the results or discussion because we argue that the most physiologically relevant normalization is total hepatic gene expression/BW. 
Table 3 Hepatic mRNA levels of igf2, Type I GH receptor (Ghr; ghr1), and Type II Ghr (ghr2) when normalized as copy number/ng total RNA. Data in this table are provided solely for purposes of qRTPCR normalization comparisons, as Fig. 4 shows data normalized to total liver copy number/body weight, which we argue is more biologically relevant. Control HSB were fed to satiation twice daily and treatment fish were subjected to 3 weeks feed restriction (days 0-21) followed by 6 weeks of refeeding (days 22-63)

\begin{tabular}{|c|c|c|c|c|c|c|}
\hline & \multicolumn{2}{|l|}{ igf2 } & \multicolumn{2}{|l|}{$g h r 1^{a}$} & \multicolumn{2}{|l|}{$g h r 2^{a}$} \\
\hline & Control & Treatment & Control & Treatment & Control & Treatment \\
\hline \multicolumn{7}{|c|}{ Day } \\
\hline 0 & $9831 \pm 1068$ & $9831 \pm 1068$ & $6886 \pm 318$ & $6886 \pm 318$ & $1109 \pm 164$ & $1109 \pm 164$ \\
\hline 21 & $14205 \pm 1731$ & $6182 \pm 497^{\dagger}$ & $7634 \pm 543$ & $6615 \pm 298$ & $1202 \pm 134$ & $1850 \pm 131^{\dagger}$ \\
\hline 29 & $13462 \pm 1654$ & $12147 \pm 1092$ & $7804 \pm 396$ & $7159 \pm 506$ & $1352 \pm 151$ & $717 \pm 92^{+}$ \\
\hline 42 & $6390 \pm 974$ & $10756 \pm 1580^{*}$ & $4395 \pm 325$ & $4693 \pm 479$ & $1643 \pm 185$ & $1387 \pm 74$ \\
\hline 63 & $7688 \pm 979$ & $7185 \pm 616$ & $5543 \pm 517$ & $4981 \pm 315$ & $1426 \pm 153$ & $1224 \pm 66$ \\
\hline
\end{tabular}

Time 0 samples were combined between groups for each gene. Statistical analyses for each gene are between groups within time. ${ }^{*} P<0 \cdot 05,{ }^{+} P<0 \cdot 001$. $N=8$ fish/group.

${ }^{\mathrm{a} A l l}$ values are divided by 100 .

\section{Plasma Igf1}

Plasma Igf1 rose slightly in control fish over the course of the experiment (Fig. 5A). By contrast, treatment HSB experienced a $61 \%$ decline in plasma Igf1 $(P<0.001)$ following feed restriction (days $0-21$ ) to a value that was significantly lower than control levels at any time during the experiment $(P<0 \cdot 001$; Fig. 5A). Upon refeeding, plasma Igf1 increased by 8 days and reached control levels by 3 weeks of realimentation, after which point levels remained similar to controls. A significant correlation was seen with plasma Igf1 and SGR $\left(R^{2}=0 \cdot 54, P<0 \cdot 001\right.$; Fig. 6). Responses in plasma Igf1 in treatment fish subjected to the $\mathrm{CG}$ feeding protocol were also similar to that observed for total hepatic igf 1 mRNA levels $\left(R^{2}=0 \cdot 50, P<0 \cdot 001\right)$.

\section{Plasma 40 kDa Igfbp}

The $40 \mathrm{kDa}$ Igfbp is thought to be a putative mammalian Igfbp-3 based on physiological responses and molecular weight (Siharath et al. 1995a,b, Shimizu et al. 2003), but according to recent phylogenic analysis may be an Igfbp-2 paralog (Rodgers et al. 2008). The $40 \mathrm{kDa}$ Igfbp in our study displays distinct expression patterns in relation to feed restriction and CG (Fig. 5B). Specifically, levels of the $40 \mathrm{kDa}$ Igfbp decreased by 74\% $(P<0 \cdot 001)$ following 3 weeks of feed restriction (days $0-21$ ) to values well below those of controls $(P<0 \cdot 001)$. Similar to that observed with circulating Igf1, the $40 \mathrm{kDa}$ Igfbp was completely restored to control values 3 weeks into the CG response when fish were refed.

\section{Skeletal muscle gene expression}

The catabolic state induced through complete feed restriction in treatment fish resulted in an $89 \%$ decrease in skeletal muscle igf1 mRNA $(P<0 \cdot 001)$ to levels significantly lower than controls $(P<0 \cdot 05$; Fig. 7a). The igf1 mRNA increased tenfold $(P<0 \cdot 001)$ from their previously depressed levels and were completely restored to control values by 8 days of realimentation. Gene expression levels were similar between control and treatment groups for the remainder of the experiment. A significant, albeit mild, correlation was derived between muscle igf $1 \mathrm{mRNA}$ and SGR $\left(R^{2}=0 \cdot 25 ; P<0 \cdot 001\right)$ in control and treatment groups. There were no significant differences in skeletal muscle igf 2 or igfr levels either within treatment across time or between treatments within time (data not shown). While there were no significant differences in muscle ghr1 mRNA expression between or within groups
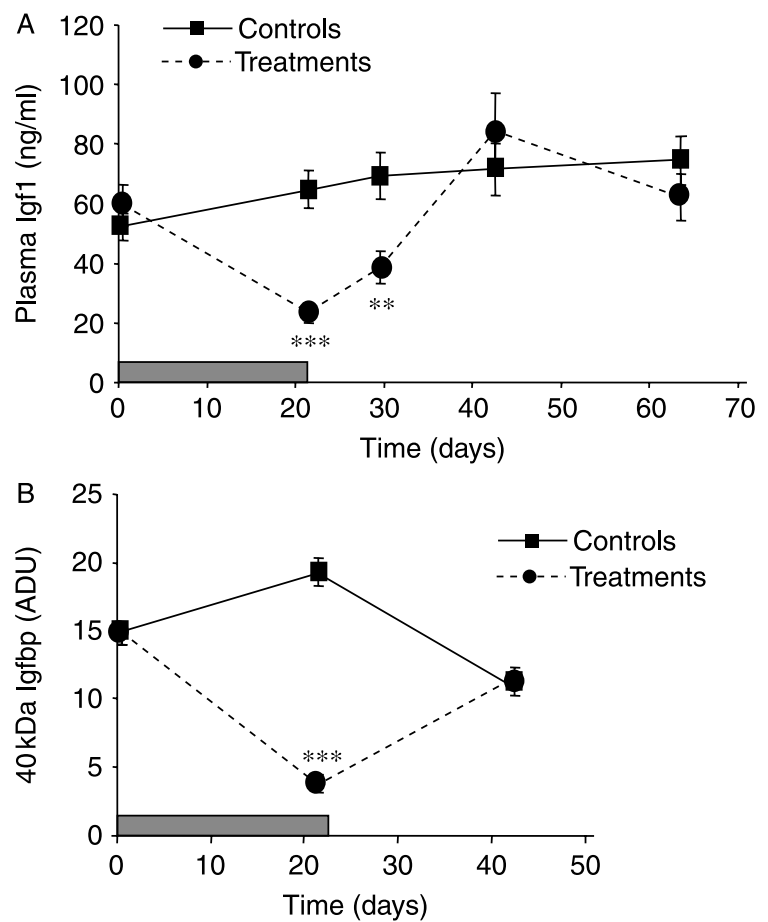

Figure 5 Plasma (A) lgf1 (ng/ml) and (B) $40 \mathrm{kDa}$ lgf-binding protein (arbitrary density units, ADU) in control HSB fed to satiation twice daily and in treatment fish subjected to 3 weeks feed restriction (grey bar) followed by 6 weeks of refeeding twice daily to satiation. Asterisks represent significant differences between groups at each time point ( ${ }^{* *} P<0 \cdot 01 ;{ }^{* * *} P<0 \cdot 001 ; N=6-8$ fish/group). 


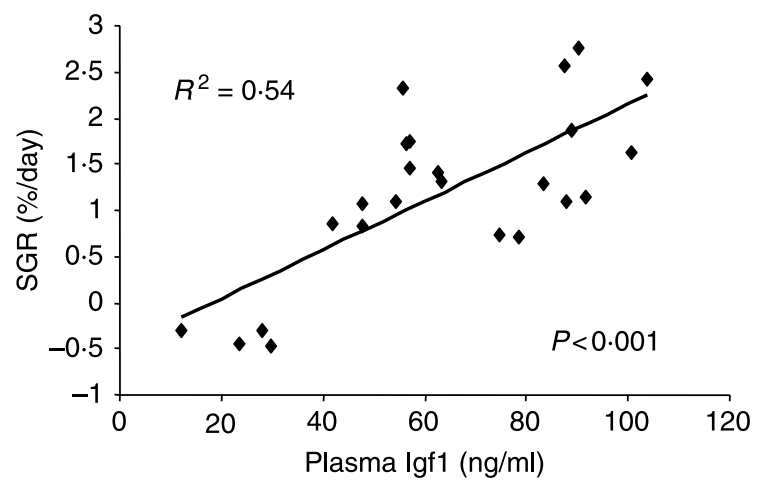

Figure 6 Correlation between plasma lgf1 $(\mathrm{ng} / \mathrm{ml})$ and specific growth rate (SGR; \%/day) in control HSB fed to satiation twice daily and in treatment fish subjected to 3 weeks feed restriction followed by 6 weeks of refeeding twice daily to satiation. Specific growth rates (days 0-21, 22-42,43-63) reflect the pairing of mean weights of fish with mean plasma Igf1 values from 8 tanks (4 tanks/group). Fish were sampled at days 21, 42, and 63.

throughout the experiment (Fig. 7b), 3 weeks of starvation in treatment fish resulted in a $340 \%$ increase in $g h r 2$ mRNA expression $(P<0 \cdot 001$; Fig. $7 \mathrm{c})$ to levels $3 \cdot 2$-fold higher than controls $(P<0 \cdot 001)$. Upon refeeding and the CG response, ghr 2 mRNA was restored to levels of control fish.

\section{Discussion}

This study demonstrates that a sufficient period of feed restriction and catabolism can induce subsequent periods of CG upon refeeding in HSB. The response is characterized by elevated SGRs, hyperphagia, and improved feed conversion. Furthermore, when hepatic gene expression data were normalized to total liver mRNA relative to body weight, significant increases were observed in igf1, igf 2 , ghr1, and ghr2 mRNA during CG, and for some of the genes the increase even exceeded that of normal animals fed continuously throughout the experiment. The CG response was also accompanied by considerable increases in plasma Igf1, a $40 \mathrm{kDa}$ Igfbp, and skeletal muscle gene expression of igf 1 . Fasting resulted in elevated muscle ghr 2 mRNA levels, which was restored to control values during CG. No change in skeletal muscle gene expression was detected for igfr, igf 2 or ghr1 during the different metabolic states associated with CG feeding protocols.

CG is a period of growth acceleration that exceeds normal rates after animals are alleviated of certain growth-stunting conditions. In fishes, feeding manipulation remains the most common means of inducing the response, with periods of feed restriction and typically some degree of weight loss being followed by satiation feeding (see Ali et al. 2003 for review). In those species where CG has been demonstrated, either partial or full catch-up growth was induced in Atlantic halibut (Heide et al. 2006), channel catfish (Gaylord \& Gatlin 2000),
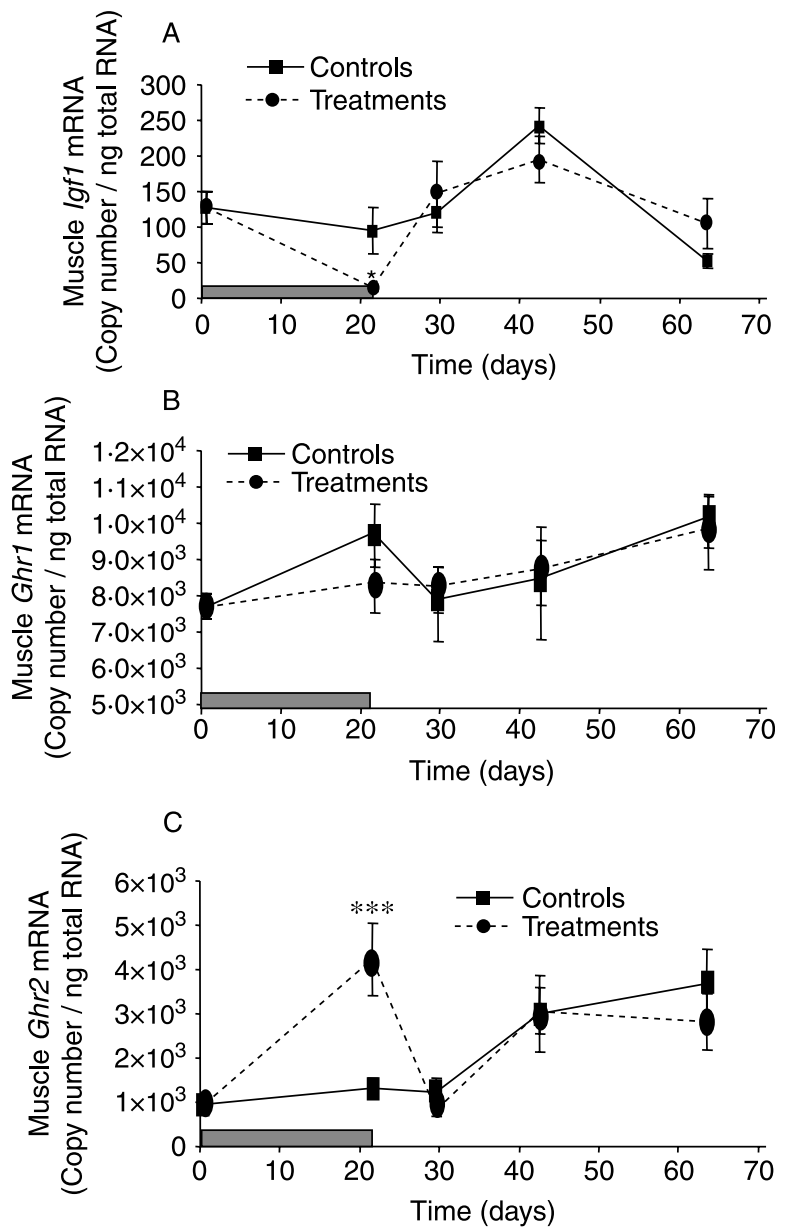

Figure 7 Skeletal muscle tissue mRNA expression of (A) insulin-like growth factor-I (igf1), (B) Type I Ghr (ghr1), and (C) Type II Ghr ( $g h r 2)$ in response to normal (control) and cyclic (treatment) feeding. Data are expressed as copy number/ng total RNA. Grey bar denotes a period of feed restriction for treatment fish. Asterisks represent significant differences between groups at each time point $\left({ }^{*} P<0 \cdot 05 ; N=8-16\right.$ fish/group).

European sea bass (Terova et al. 2006), hybrid sunfish (Hayward et al. 1997), and rainbow trout (Montserrat et al. 2007) through variations of this protocol. In HSB, partial feed restriction has led to full compensation in individually housed fish (Skalski et al. 2005), along with partial CG in grouphoused HSB in both ponds (Turano et al. 2007) and tanks (Picha et al. 2006).

In this study, we demonstrate that tank-raised, grouphoused HSB exhibit strong CG responses following complete feed restriction, and that the response is characterized by almost twofold elevations in SGR relative to control fish over the same time interval. An additional consideration that has received little attention in most CG studies (see Ali et al. 2003), including those evaluating the endocrine basis of the response, is the allometric relationship between growth rates and body mass (Jobling 1994). Indeed, smaller fish tend to 
grow faster than larger fish, raising the question as to whether elevations in SGR of growth-stunted fish are the result of their smaller body size or a 'true' CG response. We found that SGR was 50\% higher than control fish during the CG response when initial body size was accounted for (control fish days $0-21,1 \cdot 70 \% \mathrm{BW} /$ day versus treatment fish days 22$42,2 \cdot 52 \% \mathrm{BW} /$ day). This is in agreement with our earlier reports where CG was shown to occur following a period of partial feed restriction in HSB, even when accounting for potential differences in size-dependent growth rate (Skalski et al. 2005, Picha et al. 2006).

Hyperphagia and improved feed conversion were observed alongside the elevated SGRs during the CG response (days 22-42; Table 2). Hence, these behavioral and metabolic responses likely contribute to phases of accelerated growth associated with CG. Based on previous reports and results herein, it would appear that a certain catabolic threshold is necessary to drive these higher growth rates, feed consumption, and improved feed conversion. In previous studies, we found that a combination of low HSI $(<1 \cdot 5)$ and body weight loss are necessary to induce subsequent $\mathrm{CG}$ responses (Picha et al. 2006, Turano et al. 2007). In the current study, both of these conditions were met following feed restriction $(7 \cdot 7 \% \mathrm{BW}$ decrease; HSI $=1 \cdot 11)$.

Feeding manipulation protocols that induce periods of stunted (negative), normal, and accelerated (compensatory) growth can provide methods for elucidating the endocrine control of variable growth rates and its control by the Gh-Igf axis. In cattle and pigs, levels of circulating IGF1 corresponded to periods of feed restriction and CG (see Hornick et al. 2000 for review; Leon et al. 2004, Therkildsen et al. 2004). Similarly, we found that circulating Igf1 paralleled altered growth states during CG feeding protocols, declining during growth depression and increasing during CG. Likewise, total hepatic igf1 mRNA levels also changed in a fashion similar to both circulating hormone and growth, suggesting that the synthesis and secretion of hepatic Igf1 is important in mediating growth responses observed with stunted and rapid growth states. Interestingly, we found that igf $1 \mathrm{mRNA}$ levels exceeded control fish during the $\mathrm{CG}$ response, raising the possibility that extra elevated transcript levels may contribute to the rapid rise in circulating Igf1 during CG. The significant correlation between total hepatic igf 1 mRNA and circulating Igf1 supports this notion, and suggests the liver is the primary source of circulating hormone, which has been firmly established in mammalian models using selective knockouts of the hepatic igf1 gene (Sjogren et al. 1999, Yakar et al. 1999).

The majority of circulating Igf1 in fish is bound to Igfbps, making them prime mediators of the mitogenic effects of Igf1 (Shimizu et al. 1999, Duan \& Xu 2005). Based on molecular weight (MW) and physiological responses, including those in striped bass (Kelley et al. 1992, Siharath et al. 1995a,b), the $40 \mathrm{kDa}$ Igfbp detected in this study is likely the mammalian equivalent of Igfbp-3, or alternatively an Igfbp-2 paralog, which is reported to increase Igf1 half-life and regulate its availability to target tissues (Kelley et al. 2001, Shimizu et al.
2003, Rodgers et al. 2008). Levels of the $40 \mathrm{kDa}$ Igfbp paralleled those of circulating Igf1, declining during catabolism and increasing to levels of control fish by termination of the $\mathrm{CG}$ response. These studies are the first to show circulating $40 \mathrm{kDa}$ Igfbp trends during CG responses in fishes, with the strong up-regulation during realimentation possibly contributing to increasing Igfl's half-life in the plasma and the hormones elevation during CG. This also corroborates earlier studies in which similar trends in $40 \mathrm{kDa}$ Igfbp were observed with fluctuations in nutritional state of the more primitive salmonid teleosts (Beckman et al. 2004, Pierce et al. 2005). In cattle, IGFBP-3 levels corresponded to fluctuations in reduced and compensatory growth, although the onset of puberty was a confounding variable (Luna-Pinto \& Cronje 2000). Evidence in mammals also suggests that some IGFBPs may have ligand-independent mitogenic effects (see Duan \& Xu 2005), underscoring the need to further investigate their role in fishes during CG.

During catabolic states preceding CG responses or following most periods of feed restriction in fishes, a state of Gh resistance is induced in which elevated plasma $\mathrm{Gh}$ is generally countered by depressed hepatic ghr gene expression and binding, which ultimately results in low levels of both hepatic igf1 mRNA and plasma Igf1 (Gray et al. 1992, Duan et al. 1995, Pierce et al. 2005, Norbeck et al. 2007). In an alternative form of $\mathrm{Gh}$ resistance seen during feeding manipulation, plasma $\mathrm{Gh}$ increases and hepatic igf1 gene expression declines with no change in hepatic ghr mRNA (Fox et al. 2006, Gabillard et al. 2006), raising the possibility that Ghr signaling may be impaired (Beauloye et al. 2002). In our investigation, hepatic ghr1 and ghr2 mRNA levels declined during feed deprivation along with hepatic igf1 mRNA and circulating Igf1 peptide. This, along with evidence that pituitary gh mRNA, Gh content, and plasma Gh increase in these fish during the feed deprivation period (Turano 2006; unpublished results) suggests a state of Gh resistance. Furthermore, a strong correlation between both

Table 4 Correlations $\left(R^{2}\right)$ between specific growth rate (SGR) and total hepatic mRNA levels of insulin-like growth factor-I (igf1), igf2 and the Type I growth hormone $(\mathrm{GH})$ receptor ( $g h r 1)$ and Type II Ghr (ghr2). Specific growth rates were calculated from mean tank weights of control and treatment fish during days 0-21, 22-42, and 43-63 and were plotted against individual fish gene expression (mRNA) values. Correlations between gene expression (mRNA) values were derived from individual control and treatment fish on days $0,21,29,42$, and 63 .

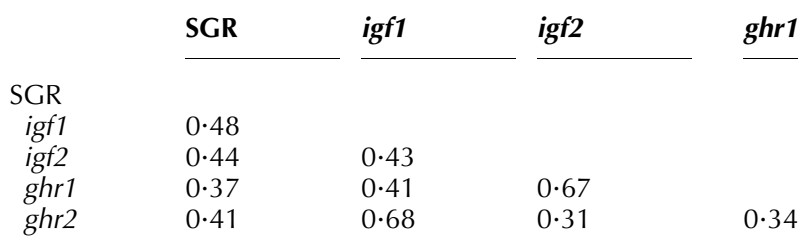

All correlations are statistically significant $(P<0 \cdot 001) . \quad N=54-80$ animals/parameter. 
ghr1 and ghr2 and igf1 mRNA (Table 4) suggests that the Ghr may be responsible for mediating Igf1 transcription, in particular during periods of $\mathrm{Gh}$ resistance and subsequent periods of CG. However, further research is required to confirm that Ghr binding declines in conjunction with mRNA levels, as has been recently shown for rainbow trout (Norbeck et al. 2007). Previous work in HSB has shown that Igf1 binds with high affinity to the pituitary and acts as a powerful negative feedback inhibitor of Gh synthesis and secretion (Fruchtman et al. 2000, 2002). It is likely, therefore, that elevations in pituitary Gh activity and plasma Gh levels are a reflection of the prevailing low circulating Igf1 seen during states of catabolism and vice versa during anabolism.

As previously indicated, we found that total hepatic igf1 mRNA levels decline during catabolism and increase upon realimentation. However, when hepatic igf1 gene expression is normalized according to standard procedures, i.e. to copy number/ng RNA or a housekeeping gene, an elevation in igf1 mRNA is observed during the catabolic state of feed deprivation in HSB (see Fig. 3A), which is similar to that we previously reported with partial feed restriction in HSB (Picha et al. 2006). Studies by others using similar normalizations have reported either increases or no change in hepatic igf1 mRNA but declines in plasma Igf1 and/or growth following feed restriction (Ayson et al. 2007, Pierce et al. 2007). The lack of concordance in hepatic igf $1 \mathrm{mRNA}$ and circulating hormone in these studies may be resolved by the use of an alternative method of mRNA normalization presented here. Since HSI fluctuates dramatically between feed restriction and CG and its values positively correlate to total liver RNA, we argue that expressing hepatic gene expression data as a function of the total amount in the organ relative to body size (total liver copy number/BW) is more physiologically appropriate than standard normalization methods. The final step of dividing by body weight puts the total hepatic mRNA production for a particular gene in an organismal context (total hepatic production per unit of body mass), which is critical when comparing gene expression trends between fish of different sizes and in variable metabolic states. Overall, the amount of transcript produced by the entire liver relative to the size of the fish provides a more accurate indication of the Igf1 levels present in the circulation (see Figs $3 \mathrm{~B}$ and $5 \mathrm{~A} ; R^{2}=0.50$ for total hepatic igf1 mRNA versus plasma Igf1). A similar qRTPCR normalization scheme was utilized in gene expression analyses of spermatogenesis in rainbow trout where testes size varies considerably with reproductive state (Kusakabe et al. 2006). Hepatic Ghr-binding assays in fed and fasted rainbow trout were also argued to be more biologically relevant when expressed as total liver binding, as opposed to Ghr binding per unit of liver weight (Yao et al. 2006). We suggest that this normalization procedure be considered for all endocrine organs whose size changes significantly with physiological state.

Relative to Igf1, little is known about the role of Igf2 in postnatal growth despite its high expression levels in the liver of fish, ability to bind with equal affinity as Igf1 to the Igf receptor, and potential for up-regulation by Gh (Shamblott et al. 1995, Fruchtman et al. 2002, Vong et al. 2003, Peterson et al. 2005, Moriyama et al. 2008). While barramundi and salmon Igf1 were more potent in stimulating protein synthesis than Igf2 in rat myoblasts (Degger et al. 2001, Wilkinson et al. 2004), injection of homologous Igf2 resulted in similar elevations in weight gain in tilapia as injection with Igf1 (Chen et al. 2000). Furthermore, Igf2 has recently been shown to have significant mitogenic effects in trout myocytes (Codina et al. 2008). In HSB, total hepatic igf 2 mRNA levels fell dramatically during feed deprivation and rose rapidly upon realimentation, eventually exceeding those of control fish by day 21 of the experiment. In fact, a significant correlation was achieved between total hepatic igf $2 \mathrm{mRNA}$ and SGR, indicating that the growth factor, assuming a similar translation pattern, could be facilitating phases of accelerated growth. This is the first study, to our knowledge, to report a correlation between SGR and any Igf2 value in fishes, including during exposure to sequential cycles of catabolism and CG. An even stronger correlation was reported between total liver ghr1 and igf2 mRNA (Table 4), supporting the idea that plasma GH may work through hepatic receptors to regulate Igf2 transcription and growth (Shamblott et al. 1995, Vong et al. 2003).

Studies in European sea bass showed that both muscle and liver igf 2 mRNA changed with growth state and feeding (Terova et al. 2007), while feed restriction in Atlantic salmon resulted in significant decreases in the circulating Igf2 peptide (Wilkinson et al. 2006). Hepatic and muscle igf2 mRNA is also higher in fast versus slow-growing families of catfish (Peterson et al. 2004), while hepatic levels of igf $2 a$ mRNA were higher in larger compared with smaller glass eels, Anguilla japonica (Moriyama et al. 2008). In rainbow trout, both hepatic igf2 mRNA and plasma Igf2 were depressed during fasting and were subsequently up-regulated during refeeding (Gabillard et al. 2006). This is in contrast to cattle where plasma Igf2 did not correspond to feed restriction and CG (Hayden et al. 1993). Our results with hepatic igf2 gene expression suggest that systemic or endocrine sources of Igf2 may contribute to the rapid growth characteristic of CG and the negative growth seen with catabolism. This, along with the research of others, strengthens the hypothesis that Igf2 might serve as an important regulator of postnatal growth in fish. It would appear based on gene expression analysis that paracrine or locally produced Igf 2 may not be contributing to differential growth in HSB, as we found no difference in muscle igf $2 \mathrm{mRNA}$ expression between control and treatment fish. Whether striped bass or its hybrids possess duplicated forms of Igf2 that might be differentially regulated with metabolic state as seen in eel (Moriyama et al. 2008) is unknown.

Aside from the endocrine effects of Igf1 and possibly Igf2, local autocrine/paracrine dynamics of Igf1 may also contribute to the phase of accelerated growth (Chauvigné et al. 2003, Luckenbach et al. 2007). In particular, transgenic 
tilapia overexpressing Ghs were twofold heavier than wild types yet had depressed levels of plasma Igf1 and elevated skeletal muscle igf1 gene expression (Eppler et al. 2007). This raises the possibility that autocrine/paracrine sources of Igf1 may be a significant contributor to somatic growth. In studies here, we found that skeletal muscle igf1 mRNA increased tenfold from previously depressed catabolic levels and was completely restored to control values by 8 days into the $\mathrm{CG}$ response. These findings and those in rainbow trout and European sea bass (Montserrat et al. 2007, Terova et al. 2007) show that paracrine Igf1 may facilitate the rapid growth characteristic of CG in fish, although studies have yet to validate that locally produced igf $1 \mathrm{mRNA}$ corresponds to protein. We speculated that the Igf receptor might increase to enhance tissue sensitivity to Igfs during CG. However, we found that gene expression of the receptor in skeletal muscle was not altered with either feed deprivation or the rapid growth phase. This does not preclude the possibility, however, that the receptor itself might be up-regulated, that an alternate form might be differentially regulated, or that it might show greater responsiveness to rapid fluctuations in systemic or local (muscle) Igf1 compared with relatively constant levels of ligand with fish on continuous daily feeding (Borski et al. 2000, Schlueter et al. 2006).

Although levels of igf1 transcript were down-regulated during fasting, skeletal muscle ghr2 expression was significantly up-regulated, while no change was observed with ghr1. We were unable to determine total muscle mRNA transcript levels as a function of body size during different metabolic states, as was done for the liver, because all muscle tissue cannot be reliably excised. Nevertheless, the elevations in skeletal muscle ghr2 mRNA during catabolism are consistent with that observed in gilthead sea bream, rainbow trout, and tilapia (Saera-Vila et al. 2005, Gabillard et al. 2006, Pierce et al. 2007), and suggest an alternative form of $\mathrm{GH}$ resistance. That is, signaling by $\mathrm{GH}$ through the Ghrs could be impaired (Beauloye et al. 2002), leading to reduced Igf1 transcription as shown here. At the same time, increased expression of $g h r 2$ mRNA and presumably its protein during fasting, in parallel with elevations in plasma GH (data not shown) could facilitate either mobilization of energy stores (i.e. amino acids; Inui et al. 1985) or, conversely, protein sparing (Gamrin et al. 2000).

In conclusion, we have found that complete feed restriction can prime $\mathrm{HSB}$ for CG responses and that this catabolic state is characterized by weight loss, a drop in HSI below threshold levels and an endocrine state of Gh resistance. During the subsequent phase of refeeding and the ensuing $\mathrm{CG}$ response, elevations in growth rates are potentially driven by a combination of hyperphagia, improved feed conversion, and heightened levels of Igf1, $40 \mathrm{kDa}$ Igfbps, and possibly Igf2. Interestingly, elevations in certain hepatic transcripts (e.g. igf2, ghr1, and ghr2) to levels exceeding those in normally fed fish might be a contributing factor to the accelerated growth rates characteristic of CG responses. Our results also suggest that paracrine/autocrine Igf1 may be contributing to enhanced growth during CG. In addition, we propose that hepatic mRNA levels of specific genes be expressed as the total amount produced by the organ relative to body weight. This method provides a more physiologically relevant idea of the amount of gene, and presumed protein, produced by a tissue whose size changes dramatically with nutritional state.

\section{Declaration of Interest}

There is no conflict of interest that would prejudice this manuscripts impartiality.

\section{Funding}

This work was supported by grants from North Carolina Sea Grant (RA/F-41 and RA/F-46), Fisheries Resource Grant (04-AM-05), USDA, and NSF (IBN-0215205).

\section{Acknowledgements}

The authors would like to acknowledge Brad Ring for fish husbandry and Jennifer Schmidt and Eugene Won for technical assistance.

\section{References}

Ali M, Nicieza A \& Wootton RJ 2003 Compensatory growth in fishes: a response to growth depression. Fish and Fisheries 4 147-190.

Ayson FG, de Jesus-Ayson EGT \& Takemura A 2007 mRNA expression patterns for GH, PRL, SL, IGF-I and IGF-II during altered feeding status in rabbitfish, Siganus guttatus. General and Comparative Endocrinology 150 196-204

Barlow JJ, Mathias AP, Williamson R \& Gammack DB 1963 A simple method for quantitative isolation of undegraded high molecular weight ribonucleic acid. Biochemical and Biophysical Research Communications 13 61-66.

Beauloye V, Willems B, deConinck V, Frank SJ, Edery M \& Thissen JP 2002 Impairment of liver GH receptor signaling by fasting. Endocrinology 143 792-800.

Beckman BR, Shimizu M, Gadberry BA \& Cooper KA 2004 Response of the somatotropic axis of juvenile coho salmon to alterations in plane of nutrition with an analysis of the relationships among growth rate and circulating IGF-I and $41 \mathrm{kDa}$ IGFBP. General and Comparative Endocrinology 135 334-344.

Borski RJ, Tsai W, Demott-Friberg R \& Barkan AL 2000 Induction of growth hormone $(\mathrm{GH})$ mRNA by pulsatile $\mathrm{GH}$-releasing hormone in rats is pattern specific. American Journal of Physiology. Endocrinology and Metabolism 278 E885-E891.

Bustin SA 2000 Absolute quantification of mRNA using real-time reverse transcription polymerase chain reaction assays. Journal of Molecular Endocrinology 25 169-193.

Chauvigné F, Gabillard JC, Weil C \& Rescan PY 2003 Effect of refeeding on IGFI, IGFII, IGF receptors, FGF2, FGF6, and myostatin mRNA in rainbow trout myotomal muscle. General and Comparative Endocrinology 132 209-215.

Chen JY, Chen JC, Chang CY, Shen SC, Chen MS \& Wu JW 2000 Expression of recombinant tilapia insulin-like growth factor-I and stimulation of juvenile tilapia growth by injection of recombinant IGFs polypeptides. Aquaculture 181 347-360. 
Codina M, Garcia de la Serrana D, Sanchez-Gurmaches J, Montserrat N, Chistyakova O, Navarro I \& Gutierrez J 2008 Metabolic and mitogenic effects of IGF-II in rainbow trout (Oncorhynchus mykiss) myocytes in culture and the role of IGF-II in the PI3K/Akt and MAPK signalling pathways. General and Comparative Endocrinology 157 116-124.

Degger B, Richardson N, Collet C \& Upton Z 2001 Production, in vitro characterization, in vivo clearance, and tissue localization of recombinant barramundi (Lates calcarifer) insulin-like growth factor II. General and Comparative Endocrinology 123 38-50.

Duan C 1997 The insulin-like growth factor system and its biological actions in fish. American Zoologist 37 491-503

Duan C \& Xu Q 2005 Roles of insulin-like growth factor (IGF) binding proteins in regulating IGF actions. General and Comparative Endocrinology 142 44-52.

Duan C, Plisetskaya EM \& Dickhoff WW 1995 Expression of insulin-like growth factor I in normally and abnormally developing coho salmon (Oncorhynchus kisutch). Endocrinology 136 446-452.

Eppler E, Caelers A, Shved N, Hwang G, Rahman AM, Maclean N, Zapf J \& Reinecke M 2007 Insulin-like growth factor-I (IGF-I) in a growthenhanced transgenic (GH-overexpressing) bony fish, the tilapia (Oreochromis niloticus): indication for higher impact of autocrine/paracrine than of endocrine IGF-I. Transgenic Research 16 479-489.

Fox BK, Riley LG, Hirano T \& Grau EG 2006 Effects of fasting on growth hormone, growth hormone receptor, and insulin-like growth factor-I axis in seawater-acclimated tilapia, Oreochromis mossambicus. General and Comparative Endocrinology 148 340-347.

Fruchtman S, Jackson L \& Borski RJ 2000 Insulin-like growth factor I disparately regulates prolactin and growth hormone synthesis and secretion: studies utilizing the teleost pituitary model. Endocrinology 141 2886-2894.

Fruchtman S, McVey DC \& Borski RJ 2002 Characterization of pituitary IGF-I receptors: modulation of prolactin and growth hormone. American Journal of Physiology. Regulatory, Integrative and Comparative Physiology 283 R468-R476.

Fukada H, Ozaki Y, Pierce AL, Adachi S, Yamauchi K, Hara A, Swanson P \& Dickhoff WW 2005 Identification of the salmon somatolactin receptor, a new member of the cytokine receptor family. Endocrinology 146 2354-2361.

Fukamachi S \& Meyer A 2007 Evolution of receptors for growth hormone and somatolactin in fish and land vertebrates: lessons from lungfish and sturgeon orthologues. Journal of Molecular Evolution 65 359-372.

Fukamachi S, Yada T \& Mitani H 2005 Medaka receptors for somatolactin and growth hormone: phylogenetic paradox among fish growth hormone receptors. Genetics 171 1875-1883.

Gabillard JC, Kamangar BB \& Montserrat N 2006 Coordinated regulation of the GH/IGF system genes during refeeding in rainbow trout (Oncorhynchus mykiss). Journal of Endocrinology 191 15-24.

Gamrin L, Essen P, Hultman E, McNurlan MA, Garlick PJ \& Wernerman J 2000 Protein-sparing effect in skeletal muscle of growth hormone treatment in critically ill patients. Annals of Surgery 231 577-586.

Gaylord GT \& Gatlin DM III 2000 Assessment of compensatory growth in channel catfish Ictalurus punctatus R. and associated changes in body condition indices. Journal of the World Aquaculture Society 31 326-336.

Gray ES, Kelley KM, Law S, Tsai R, Young G \& Bern HA 1992 Regulation of hepatic growth hormone receptors in coho salmon (Oncorhynchus kisutch). General and Comparative Endocrinology 88 243-252.

Hayden JM, Williams JE \& Collier RJ 1993 Plasma growth hormone, insulinlike growth factor, insulin and thyroid hormone association with body protein and fat accretion in steers undergoing compensatory growth after dietary energy restriction. Journal of Animal Science 71 3327-3338.

Hayward RS, Noltie DB \& Wang N 1997 Use of compensatory growth to double hybrid sunfish growth rates. Transactions of the American Fisheries Society 126 316-322.

Heide A, Foss A, Stefansson SO, Mayer I, Norberg B, Roth B, Jenssen MD, Nortvedt R \& Imsland AK 2006 Compensatory growth and fillet crude composition in juvenile Atlantic halibut: effects of short term starvation periods and subsequent feeding. Aquaculture 261 109-117.

Hornick JL, Van Eenaeme C, Gerard O, Dufrasne I \& Istasse L 2000 Mechanisms of reduced and compensatory growth. Domestic Animal Endocrinology 19 121-132.
Inui Y, Miwa S \& Ishioka H 1985 Effect of mammalian growth hormone on amino nitrogen mobilization in the eel. General and Comparative Endocrinology 59 287-294.

Jiao B, Huang X, Chan CB, Zhang L, Wang D \& Cheng CHK 2006 The co-existence of two growth hormone receptors in teleost fish and their different signal transduction, tissue distribution and hormonal regulation of expression in seabream. Journal of Molecular Endocrinology 36 23-40.

Jobling M 1994 Fish Bioenergetics. p 309. London: Chapman and Hall.

Kamangar BB, Gabillard J-C \& Bobe J 2006 Insulin-like growth factorbinding protein (IGFBP) $-1,-2,-3,-4,-5$ and -6 and IGFBP-related protein 1 during rainbow trout postvitellogenesis and oocyte maturation: molecular characterization, expression profiles, and hormonal regulation. Endocrinology 147 2399-2410.

Kelley KM, Siharath K \& Bern HA 1992 Identification of insulin-like growth factor-binding proteins in the circulation of four teleost species. Journal of Experimental Zoology 263 220-224.

Kelley KM, Haigwood JT, Perez M \& Galima MM 2001 Serum insulin-like growth factor binding proteins (IGFBPs) as markers for anabolic/catabolic condition in fishes. Comparative Biochemistry and Physiology, Part B 129 229-236.

Kelley KM, Price TD, Galima MM, Sak K, Reyes JA, Zepeda O, Hagstrom RK, Truong TA \& Lowe C 2006 In Insulin-Like Growth Factor-Binding Proteins (IGFBPs) in Fish: Beacons for (Disrupted) Growth Endocrine Physiology, Vol 1, Fish Endocrinology, pp 167-195. Eds M Reinecke, G Zaccone \& BG Kapoor. Enfield, NH: Science Publishers.

Kusakabe M, Nakamura I, Evans J, Swanson P \& Young G 2006 Changes in mRNAs encoding steriodogenic acute regulatory protein, steroidogenic enzymes and receptors for gonadotropins during spermatogenesis in rainbow trout testes. Journal of Endocrinology 189 541-554.

Leon HV, Hernandez-Ceron J, Keisler DH \& Gutierrez CC 2004 Plasma concentrations of leptin, insulin-like growth factor, and insulin in relation to changes in body condition score in heifers. Journal of Animal Science 82 445-451.

Li Y, Xiaochun L, Zhang Y, Zhu P \& Lin H 2007 Molecular cloning, characterization and distribution of two types of growth hormone receptor in orange-spotted grouper (Epinephelus coioides). General and Comparative Endocrinology 152 111-122.

Luckenbach JA, Murashige M, Daniels HV, Godwin J \& Borski RJ 2007 Temperature affects insulin-like growth factor I and growth of juvenile southern flounder, Paralichthys lethostigma. Comparative Biochemistry and Physiology. Part A, Molecular and Integrative Physiology 146 95-104.

Luna-Pinto G \& Cronje PB 2000 The roles of the insulin-like growth factor system and leptin as possible mediators of the effects of nutritional restriction on age at puberty and compensatory growth in dairy heifers. South African Journal of Animal Science 30 155-163.

Montserrat N, Gabillard JC, Capilla E, Navarro MI \& Gutiérrez J 2007 Role of insulin, insulin-like growth factors, and muscle regulatory factors in the compensatory growth of the trout (Oncorhynchus mykiss). General and Comparative Endocrinology 150 462-472.

Moriyama S, Yamaguchi K, Takasawa T, Chiba H \& Kawauchi H 2008 Identification of two insulin-like growth factor IIs in Japanese eel, Anguilla japonica: cloning, tissue distribution, and expression after growth hormone treatment and seawater acclimation. Comparative Biochemistry and Physiology, Part B 149 47-57.

Nanodrop Technical Support Bulletin T009. www.nanodrop.com.

Norbeck LA, Kittilson JD \& Sheridan MA 2007 Resolving the growthpromoting and metabolic effects of growth hormone: differential regulation of GH-IGF-I system components. General and Comparative Endocrinology $151332-341$.

Pérez-Sánchez J \& Le Bail P-Y 1999 Growth hormone axis as marker of nutritional status and growth performance in fish. Aquaculture 177 117-128.

Peterson BC, Waldbieser GC \& Bilodeau L 2004 IGF-I and IGF-II mRNA expression in slow and fast growing families of USDA103 channel catfish (Ictalurus punctatus). Comparative Biochemistry and Physiology, Part A 139 317-323.

Peterson BC, Waldbieser GC \& Bilodeau L 2005 Effects of recombinant bovine somatotropin on growth and abundance of mRNA for IGF-I and IGF-II in channel catfish (Ictalurus punctatus). Journal of Animal Science $\mathbf{8 3}$ 816-824. 
Picha ME, Silverstein JT \& Borski RJ 2006 Discordant regulation of hepatic IGF-I mRNA and circulating IGF-I during compensatory growth in a telost, the hybrid striped bass (Morone chrysops $\times$ Morone saxatilis). General and Comparative Endocrinology 147 196-205.

Picha ME, Turano MJ, Beckman B \& Borski RJ 2008 Endocrine biomarkers of growth and applications to aquaculture: a mini-review of growth hormone, insulin-like growth factor-I and IGF binding proteins as growth indicators in fish. North American Journal of Aquaculture 70 196-211.

Pierce AL, Shimizu M, Beckman BR, Baker DM \& Dickhoff WW 2005 Time course of the GH/IGF axis response to fasting and increased ration in Chinook salmon (Oncorhynchus tshawytscha). General and Comparative Endocrinology 140 192-202.

Pierce AL, Fox BK, Davis LK, Visitacion N, Kitahashi T, Hirano T \& Grau EG 2007 Prolactin receptor, growth hormone receptor, and putative somatolactin receptor in Mozambique tilapia: tissue specific expression and differential regulation by salinity and fasting. General and Comparative Endocrinology 154 31-40.

Reinecke M 2006 Insulin-Like Growth Factor I and II in Fish, Vol 1, Fish Endocrinology, pp 87-130. Eds M Reinecke, G Zaccone \& BG Kapoor. Enfield, NH: Science Publishers.

Rodgers BD, Roalson EH \& Thompson C 2008 Phylogenetic analysis of the insulin-like growth factor binding protein (IGFBP) and IGFBP-related protein gene families. General and Comparative Endocrinology (In Press).

Saera-Vila A, Calduch-Giner J-A \& Perez-Sanchez J 2005 Duplication of growth hormone receptor (GHR) in fish genome: gene organization and transcriptional regulation of GHR type I and II in gilthead sea bream (Sparus aurata). General and Comparative Endocrinology 142 193-203.

Schlueter PJ, Royer T, Farah MH, Laser B, Chan SJ, Steiner DF \& Duan C 2006 Gene duplication and functional divergence of the zebrafish insulinlike growth factor 1 receptors. FASEB Journal 20 E462-E471.

Shamblott MJ, Cheng CM, Bolt D \& Chen TT 1995 Appearance of insulinlike growth factor mRNA in the liver and pyloric ceca of a teleost in response to exogenous growth hormone. PNAS 92 6943-6946.

Shimizu M, Swanson P \& Dickhoff WW 1999 Free and protein-bound insulin-like growth factor-I (IGF-I) and IGF-binding proteins in plasma of Coho salmon, Oncorhynchus kisutch. General and Comparative Endocrinology 115 398-405.

Shimizu M, Swanson P, Fukada H, Hara A \& Dickhoff WW 2000

Comparison of extraction methods and assay validation for salmon insulinlike growth factor-I using commercially available components. General and Comparative Endocrinology 119 26-36.

Shimizu M, Swanson P, Hara A \& Dickhoff WW 2003 Purification of a $41-\mathrm{kDa}$ insulin-like growth factor binding protein from serum of Chinook salmon, Oncorhynchus tshawytscha. General and Comparative Endocrinology 132 103-111.

Siharath K, Nishioka RS \& Bern HA 1995a In vitro production of IGFbinding proteins (IGFBPs) by various organs of the striped bass, Morone saxatilis. Aquaculture 135 195-202.

Siharath K, Nishioka RS, Madsen SS \& Bern HA $1995 b$ Regulation of IGFbinding proteins by growth hormone in the striped bass, Morone saxatilis. Molecular Marine Biology and Biotechnology 4 171-178.

Sjogren K, Liu J-L, Blad K, Skrtic S, Vidal O, Wallenius V, LeRoith D, Tornell J, Isaksson OGP, Jansson J-O et al. 1999 Liver-derived insulin-like growth factor-I is the principal source of IGF-I in blood but is not required for postnatal body growth in mice. PNAS 96 7088-7092.

Skalski GT, Picha ME, Gilliam JF \& Borski RJ 2005 Variable intake, compensatory growth, and increased growth efficiency in fish: models and mechanisms. Ecology 86 1452-1462.

Steele R GD \& Torrie JH 1980 Principles and Procedures of Statistics: A Biometrical Approach. New York, NY: McGraw-Hill.
Sutter NB, Bustamante CD, Chase K, Gray MM, Zhao K, Zhu L, Padhukasahasram B, Karlins E, Davis S, Jones PG et al. 2007 A single IGF1 allele is a major determinant of small size in dogs. Science 316 112-115

Terova G, Bernardini G, Binelli G, Gornati R \& Saroglia M 2006 cDNA encoding sequences for myostatin and FGF6 in sea bass (Dicentrarchus labrax, L.) and the effect of fasting and refeeding on their abundance levels. Domestic Animal Endocrinology 30 304-319.

Terova G, Rimoldi S, Chini V, Gornati R, Bernardini G \& Saroglia M 2007 Cloning and expression of insulin-like growth factor I and II in liver and muscle of sea bass (Dicentrarchus labrax, L.) during long-term fasting and refeeding. Journal of Fish Biology 70 219-233.

Therkildsen M, Vestergaard M, Busk H, Jensen MT, Riis B, Karlsson AH, Kristensen L, Ertbjerg P \& Oksberg N 2004 Compenstory growth in slaughter pigs - in vitro muscle protein turnover at slaughter, circulating IGF-I, performance and carcass quality. Livestock Production Science $\mathbf{8 8}$ 63-75.

Turano MJ 2006. Effect of cyclic feeding on compensatory growth and water quality in hybrid striped bass, Morone chrysops $\times$ M. saxatilis culture. $P h D$ dissertation. North Carolina State University, Raleigh, North Carolina.

Turano MJ, Borski RJ \& Daniels HV 2007 Compensatory growth of pondreared hybrid striped bass (Morone chrysops $\times M$. saxitilis) fingerlings. Journal of the World Aquaculture Society 38 250-261.

Uchida K, Kajimura S, Riley LG, Hirano T, Aida K \& Grau EG 2003 Effects of fasting on growth hormone/insulin-like growth factor I axis in the tilapia, Oreochromis mossambicus. Comparative Biochemistry and Physiology, Part A 134 429-439.

Vera Cruz EM, Brown CL, Luckenbach JA, Picha ME, Bolivar RB \& Borski RJ 2006 Insulin-like growth factor-I cDNA cloning, gene expression and potential use as a growth rate indicator in Nile tilapia, Oreochromis niloticus. Aquaculture 251 585-595.

Vong QP, Chan KM \& Cheng CHK 2003 Quantification of common carp (Cyprinus carpio) IGF-I and IGF-II mRNA by real-time PCR: differential regulation of expression by GH. Journal of Endocrinology 178 513-521.

Wilkinson RJ, Elliott P, Carragher JF \& Francis G 2004 Expression, purification, and in vitro characterization of recombinant salmon insulinlike growth factor-II. Protein Expression and Purification 35 334-343.

Wilkinson RJ, Porter M, Woolcott H, Longland R \& Carragher JF 2006 Effects of aquaculture related stressors and nutritional restriction on circulating growth factors (GH, IGF-I and IGF-II) in Atlantic salmon and rainbow trout. Comparative Biochemistry and Physiology, Part A 145 214-224.

Wilson PN \& Osbourn DF 1960 Compensatory growth after undernutrition in birds and mammals. Biological Reviews 35 324-363.

Wood AW, Duan CM \& Bern HA 2005 Insulin-like growth-factor signaling in fish. International Review of Cytology: A Survey of Cell Biology 243 215-285.

Yakar S, Liu J-L, Stannard B, Butler A, Accili D, Sauer B \& LeRoith D 1999 Normal growth and development in the absence of hepatic insulin-like growth factor-I. PNAS 96 7324-7329.

Yao K, Gabillard JC \& Le Bail PY 2006 Influence of circulating GH levels on GH binding capacity measurements in the hepatic membrane of rainbow trout (Oncorhynchus mykiss): importance of normalization results. Fish Physiology and Biochemistry 32 121-130.

Received in final form 11 June 2008

Accepted 10 July 2008

Made available online as an Accepted Preprint 15 July 2008 